\title{
Vigilance in pre-nesting male geese: mate guarding or predator detection?
}

\author{
Karl Frafjord
}

Frafjord, K. 2004. Vigilance in pre-nesting male geese: mate guarding or predator detention? - Ornis Norvegica 27: $48-58$.

Several studies have concluded that vigilance decreases with group size. Two main hypotheses for vigilance in males have been proposed: 1) mate guarding (including protection of paternity) and 2) predator detection. Geese often live in large groups and are easy to observe. They are thus prime candidates for studies of male vigilance and agonistic behaviour. In this study, two species of pre-nesting geese were studied. Pink-footed Geese Anser brachyrhynchus were studied on their breeding grounds on Svalbard and in a spring staging area on the northwest coast of Norway, and Bean Geese A. fabalis were studied in a spring staging area in the north-eastern corner of Norway. Observations were made of pairs of geese during foraging bouts, recording foraging, vigilance and agonistic behaviour. Group size, distance between the male and female of a pair, and position in the group (one site only) were also recorded. Few significant relationships were found, the most striking one was that males were more vigilant at the edge of the group than in the centre. In some cases, a non-linear relation was found, i.e. between group size and vigilance in one area. Overall, hypothesis 2) was more strongly supported than hypothesis 1), but most likely the males were making the best of these conflicting interests. The near total absence of a group-size effect was not consistent with the predictions or with earlier findings, indicating that the relations may be more complex than previously suggested.

Karl Frafjord, Troms $\phi$ Museum, University of Troms $\phi, 9037$ Troms $\phi$, Norway.E-mail: karlf@tmu.uit.no

\section{INTRODUCTION}

The functions and effects of vigilance have been discussed by a number of authors (reviews in Elgar 1989, Quenette 1990, Roberts 1996). According to Quenette (1990) its main functions are: (1) detection of predators, (2) observation of group members, (3) location of food, and (4) avoidance of kleptoparasitism. The benefits of foraging in groups would be that each individual can spend less time being vigilant and more time foraging, so that individual vigilance decreases as group size (or collective vigilance) increases. Elgar (1989) stated that most studies failed to demonstrate this unambiguously, and that a number of confounding factors might influence the relationship between vigilance and group size. The relationship between vigilance and group size could be expected to be non-linear, i.e. when the group exceeds a certain size there are no further benefits or the costs exceed the benefits. On the other hand, predator risk reduction or the dilution effect may even apply in the largest groups (sensu Roberts 1996).

Many arctic-nesting geese live in large groups throughout the year, but groups in some species tend to be smaller when nesting and chickrearing. An increase in group-size may lead to increased competition for food or conflicts over mates resulting in increased aggression (Black \& Owen 1988, Kotrschal et al. 1993), both of which may be enhanced during migration and pre-breeding. An increase in proportion of vigilant birds with group size has been found, e.g. in Whitefronted Geese Anser albifrons (Lazarus 1978). In 
Brent Geese Branta bernicla however, an effect of group size on vigilance was partly attributed to the edge effect, i.e. in larger flocks relatively fewer birds will be on the edge where vigilance is needed most (Inglis \& Lazarus 1981). Black et al. (1992) concluded that the energetic payoff for birds in edge positions was higher than that of birds in the middle of the group, due to food in the centre being depleted first, but their methods were criticised by Gauthier (1994).

Flock geometry is also an important variable that can influence scanning behaviour (Bekoff 1995, sensu Hamilton 1971). Lima \& Zollner (1996) concluded that collective detection was a more important result of living in groups than the dilution effect. In Ostriches Struthio camelus, sex, flock size, distance to flock, nearest neighbour distance, and park (region) accounted for most of the variance in vigilance (Burger \& Gochfeld 1988). Solitary ostriches spent more time with their heads up and less time feeding than those in groups. An increase in male vigilance was found in groups larger than seven birds, and was attributed to increased male-male competition (Burger \& Gochfeld 1988). In White-tailed Ptarmigan Lagopus leucurus, predator detection seemed more important for male vigilance and mate-guarding than protection of paternity (Artiss \& Martin 1995).

In this study, two main hypotheses are examined (Burger \& Gochfeld 1988, Artiss \& Martin $1995)$; 1) the protection of partner hypothesis (mate guarding) and 2) the predator detection hypothesis. These are not mutually exclusive. The following predictions can be outlined as a reaction to three factors; group size, distance between the members of a pair, and position in the group (Table 1). For mate guarding: (a) Vigilance and agonistic behaviour increase whereas the distance between the members of a pair decreases with group size. (b) Vigilance increases with distance between the two in a pair, whereas agonistic behaviour is not correlated with distance. (c) Vigilance and agonistic behaviour decrease as the pair moves toward the edge of the group, while distance may increase. For predator detection: (d) Vigilance decreases with group size, whereas the distance between the two in a pair remains independent of group size. (e) Vigilance is not correlated with distance. (f) Vigilance increases as the pair moves toward the edge of the group, distance may decrease. (g) Agonistic behaviour is not correlated with any of the three factors.

\section{MATERIALS AND METHODS}

\section{Observations}

Observations of geese were made in three locations (Figure 1). Pink-footed Geese Anser brachyrhynchus were observed on their breeding grounds in Sassendalen on Svalbard in 1994, and during a stop-over on their spring migration in Vesterålen on the west coast of northern

Table 1. Summary of the hypotheses (see text) $++=$ increase, $-=$ decrease, $N . a .=$ not affected .

\section{Group size Distance Position tow. edge}

\begin{tabular}{llccc}
\hline \multirow{2}{*}{ Mate guarding } & Vigilance & + & + & - \\
& Agonistic & + & N.a. & - \\
\multirow{3}{*}{ Predator detection } & Distance & - & & + \\
& Vigilance & - & N.a. & N.a. \\
& Agonistic & N.a. & & N.a. \\
& Distance & N.a. & & - \\
\hline
\end{tabular}




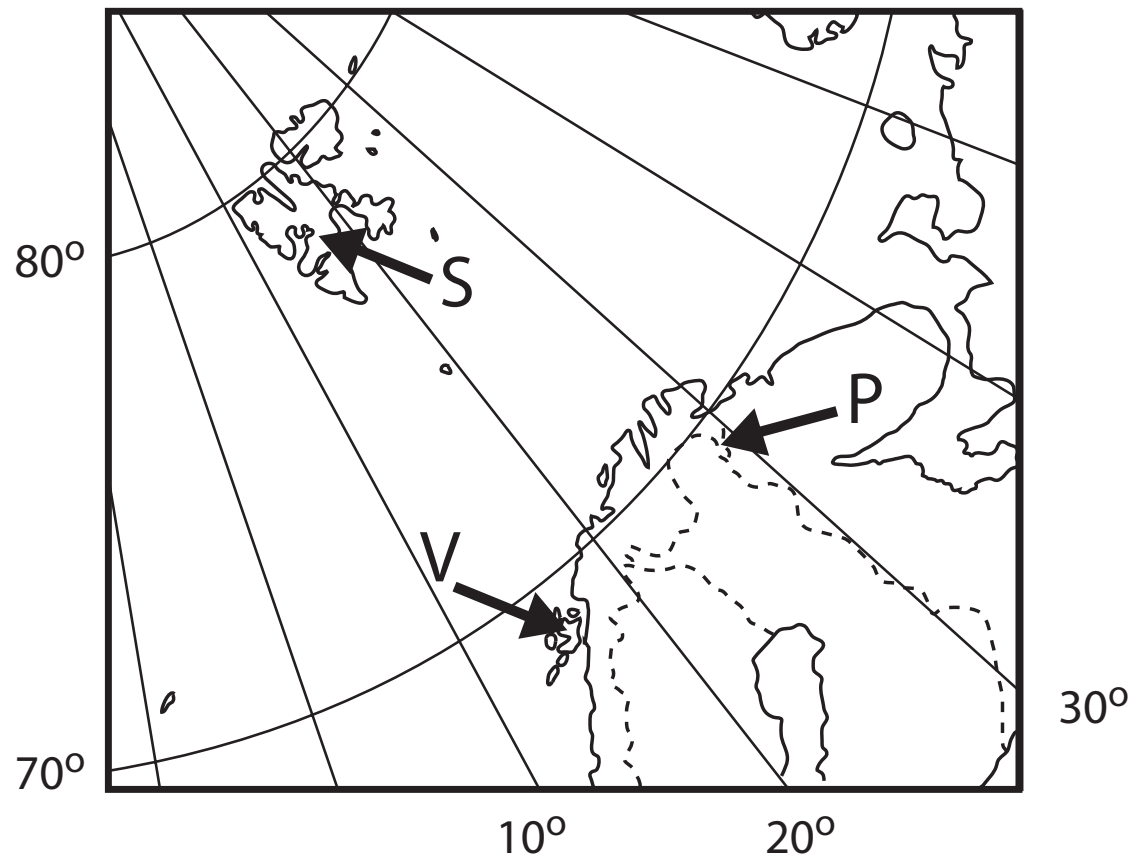

Figure 1. Map showing the position of the tree study areas; Vesterålen (V), Pasvik (P) and Sassendalen (S).

Norway in 1995. Bean Geese A. fabalis were observed in Pasvik (Pasvik river at Fjærvann) in the easternmost part of northern Norway in 1996. Observations followed the same scheme, although all factors were not recorded in all three locations. Recordings were made by focal-animal sampling of a pair of foraging geese, i.e. the behaviour of both male and female was recorded simultaneously. A foraging bout was defined as when at least one member of the pair was actively foraging (head and neck below horizontal, bill toward or in the ground).

The behaviour of the male and female was recorded at intervals of 30 seconds for 15 minutes (in Vesterålen some of the recordings were made at 60 second intervals). If both geese terminated foraging for more than three minutes, observations were ended and the period up to the point of termination used as a foraging bout. Fewer than 10 recordings were discarded from the analysis. Most observations were made during the daytime hours (07.00-22.00 hours).
After one pair had been observed, the next pairs were chosen successively farther away from the first to avoid multiple recordings of the same pair, although pseudoreplication was not completely avoided at any study site.

Vigilance included both head-up and extreme head-up (Lazarus 1978). Agonistic behaviour included all threats, attacks or chases of other geese (Lazarus \& Inglis 1978), although withinpair «aggression» was not included. «Other geese» could be both individual geese or pairs, and included offspring from the previous year. Foraging, vigilance and agonistic behaviour are all mutually exclusive behaviours. The male and female of a pair were identified on the basis of the male's larger size and often paler plumage, and on the abdominal profile (compare e.g. Owen 1981, Jeugd \& Blaakmeer 2001).

Other factors recorded were group size, distance between the two members of a pair, and position in the group. Group size or number of geese at 
the site of the focal pair was counted at regular intervals, or at the end of the observation period for a pair when new geese had arrived or left during the observations. In Vesterålen, a group included all geese on a single field. The distance between the two members of the focal pair was recorded approximately as «goose lengths», and the maximum number of goose lengths during the observation period was used. The pair's position in the group was noted; either as on the edge, or behind the edge-in the centre of the group.

Statistics include Mann-Whitney and Wilcoxon signed-rank tests (z-score, two-tailed), ANOVA with Scheffé multiple comparison test, simple factorial ANOVA (GLM), linear regression, nonlinear curve estimation, and Pearson's product moment correlation. Percentages of the various behaviours were calculated for every recording period and arcsine-transformed to better conform to normality. Untransformed data are presented in the figure.

\section{Study areas}

In Sassendalen, the study period was from the day the first geese arrived until most started to lay eggs and incubate (22 May to 8 June). The foraging site where geese were observed was one of the most important spring foraging sites in the region, and was probably used by geese breeding all over the valley Sassendalen and by geese from other valleys as well. Thus, only some of the geese foraging there nested nearby, and only one pair actually nested at the site. The only possible predator of adult geese was the Arctic Fox Alopex lagopus, and two geese were killed in this area during the study period. The Pink-footed Goose has a long history of human persecution in Svalbard, and can be extremely shy to humans (Frafjord 1990). Consequently, all observations were made from an observation tent, and any activity outside this tent was restricted as much as possible. The geese quickly adapted to the tent, and could forage quietly close to it. There was no other human activity in the region during the study period, except for the noise of a helicopter some distance away a few times. When the number of geese foraging at the site was small, no more than one or two recordings of all pairs present were taken that day to avoid multiple recordings of the same pair.

On their way to Svalbard, the Pink-footed Geese «stop-over» in Vesterålen. The first few geese (10) arrived in Vesterålen 19 April 1995 (Bønes 1995). Observations were made during 1-22 May, by which time almost all geese had left. The geese foraged on cultivated fields along the coast (Madsen 1998). A high degree of human activity could compose a «disturbance threat», and some farmers actively chased the geese off their fields. The Pink-footed Goose did not pay attention to small cars, but were wary of large trucks. They foraged close to roads and settlements when left in peace, and most «disturbance» took the form of deliberate chasing of the geese. Possible predators include the Red Fox Vulpes vulpes, the White-tailed Eagle Haliaeetus albicilla, and perhaps the Mink Mustela vison. No predation was witnessed, but the geese instantly flew up when a White-tailed Eagle passed over. They often reacted to Herons Ardea cinerea in a similar manner, possibly mistaken them for eagles, sensu Madsen (1998). All observations were made from a car parked at the end of the field. The size of the largest groups (more than 100-200 geese) was only estimated.

The first Bean Goose (two geese) arrived in Pasvik on 30 April 1996 and the majority in the middle of May (S. Wikan, pers. comm.). Observations were made during 18-27 May, when a relatively large number of geese foraged in the Pasvik river along the border between Norway and Russia. Observations ended when most geese had left for their nesting sites. Little is known about the Norwegian Bean Goose and their migration. The Pasvik river is wide, but relatively shallow, and the geese foraged on exposed, dry parts of the river, along the ice edge in shallow water, or in water as deep as their neck and head could extend (the river ice had partly broken up). They were never seen out of the river, where the snow cover 
was still relatively deep. The river is bordered by pine forest. Possible predators were the same species as in Vesterålen, with a possible addition of the Golden Eagle Aquila chrysaëtos. Human activity was small during the study period. A few Russian fishermen were seen on the river, and a few birders on land at one site only. When the geese were disturbed, they most often flew only a short distance to another part of the river. All observations was made from one, slightly elevated site on the shore, with no use of blind, but partly hidden.

\section{RESULTS}

A higher level of male vigilance was found in Sassendalen compared to Vesterålen, while vigilance in Pasvik was intermediate and not significantly different from either of the other two regions (Table 2). None of the predicted relationships were significant (Tables 3-4), i.e. neither group size nor distance between the two in a pair affected vigilance or agonistic behaviour in male geese. This supports the predator defence hypotheses more than the mate guarding hypothesis (compare Table 5 and Table 1). A small, positive correlation between group size and distance was found in Sassendalen, which may also support the predator defence hypotheses most. Vigilance was negatively correlated with foraging in all three areas as could be expected, since the two behaviours are mutually exclusive.

In Vesterålen, males were much more vigilant at the edge of the group than when inside the group $(20.1 \pm 19.9 \%$ vs.7.9 $\pm 10.9 \%, z=6.38$, $\mathrm{p}=0.000$ ), which supports the predator defence hypotheses. No effect of position in the group on agonistic behaviour was found $(z=1.59$, $\mathrm{p}>0.05)$. The distance between the members of a pair was greater in the centre of the group (4.1 \pm 1.8 vs. $3.5 \pm 1.7$ goose lengths, $z=3.25$, $\mathrm{p}=0.001)$. In Vesterålen, the different fields where goose foraged could be divided into «disturbed fields» (people chased geese away) and «undisturbed fields» (no chasing witnessed). The disturbed fields could thus mimic a higher predator pressure. The group size was larger in undisturbed fields (136.8 vs. 100.5 geese, $\mathrm{z}=4.6$, $\mathrm{p}=0.000$ ), but no significant differences in male vigilance, agonistic behaviour or foraging were found. Females on the other hand, foraged more in undisturbed fields (91.1 vs. $87.9 \%, \mathrm{z}=2.3$, $\mathrm{p}=0.02)$ and were less vigilant (1.4 vs. $3.6 \%$, $\mathrm{z}=4.0, \mathrm{p}=0.000$ ) there.

A significant non-linear relationship was found in a few cases: vigilance vs. group size in Vesterålen, distance vs. group size in Sassendalen and in Pasvik (Figure 2). Foraging was also nonlinearly related to group size. However, the data included relatively few larger groups, so these parts of the curves are more uncertain.

Table 2. Mean \pm SD percent time spent foraging, being vigilant or agonistic in male geese in Vesterålen, Sassendalen and Pasvik, and mean \pm SD distance (goose lengths) between the male and female of a pair.

\begin{tabular}{lccccc}
\hline & Vesterålen & Sassendalen & Pasvik & $\mathrm{F}^{1)}$ & $\mathrm{P}$ \\
\hline Foraging & $74,5 \pm 21.9$ & $62.0 \pm 21.4$ & $50.7 \pm 21.3$ & 60.4 & 0.000 \\
Vigilant & $14.8 \pm 17.6$ & $22.2 \pm 19.0$ & $18.0 \pm 20.6$ & 14.0 & 0.000 \\
Agonistic & $0.6 \pm 1.9$ & $0.7 \pm 2.2$ & $0.7 \pm 1.9$ & - & \\
Distance & $3.8 \pm 1.8$ & $5.3 \pm 3.0$ & $1.4 \pm 0.5$ & 32.2 & 0.000 \\
\hline
\end{tabular}

1) ANOVA tests between the three regions 
Table 3. Pearson's correlation coefficients for variables in Vesterålen (top right half, $n=349-354$ ) and Sassendalen (bottom left half, $n=311-315$ ). $* *=p<0.01$

\begin{tabular}{lccccc}
\hline & Vigilance & Agonistic & Forage & Group size & Distance \\
\hline Vigilance & - & -0.10 & $-0.75^{* *}$ & -0.06 & -0.05 \\
Agonistic & -0.06 & - & -0.08 & 0.03 & 0.00 \\
Forage & $-0.69 * *$ & -0.10 & - & 0.06 & -0.04 \\
Group size & -0.10 & 0.00 & $0.17 * *$ & - & -0.06 \\
Distance & -0.03 & -0.09 & -0.03 & $0.15^{* *}$ & - \\
\hline
\end{tabular}

Table 4. Pearson's correlation coefficients for variables in Pasvik $(n=89)$. ** $=p<0.01$

\begin{tabular}{lcccc}
\hline & Agonistic & Forage & Group size & Distance \\
\hline Vigilance & -0.13 & $-0.57 * *$ & -0.10 & 0.03 \\
Agonistic & & 0.16 & -0.06 & -0.18 \\
Forage & & & -0.03 & -0.07 \\
Group size & & & & 0.08 \\
\hline
\end{tabular}

Table 5. Summary of the results. $+=$ increase,$-=$ decrease, $N . a .=$ not affected. Compare the hypotheses in Table 1.

\begin{tabular}{lccc}
\hline & Group size & Distance & Position tow. edge \\
\hline Vigilance & N.a. & N.a. & + \\
Agonistic & N.a. & N.a. & N.a. \\
Distance & $(+)$ & & - \\
\hline
\end{tabular}



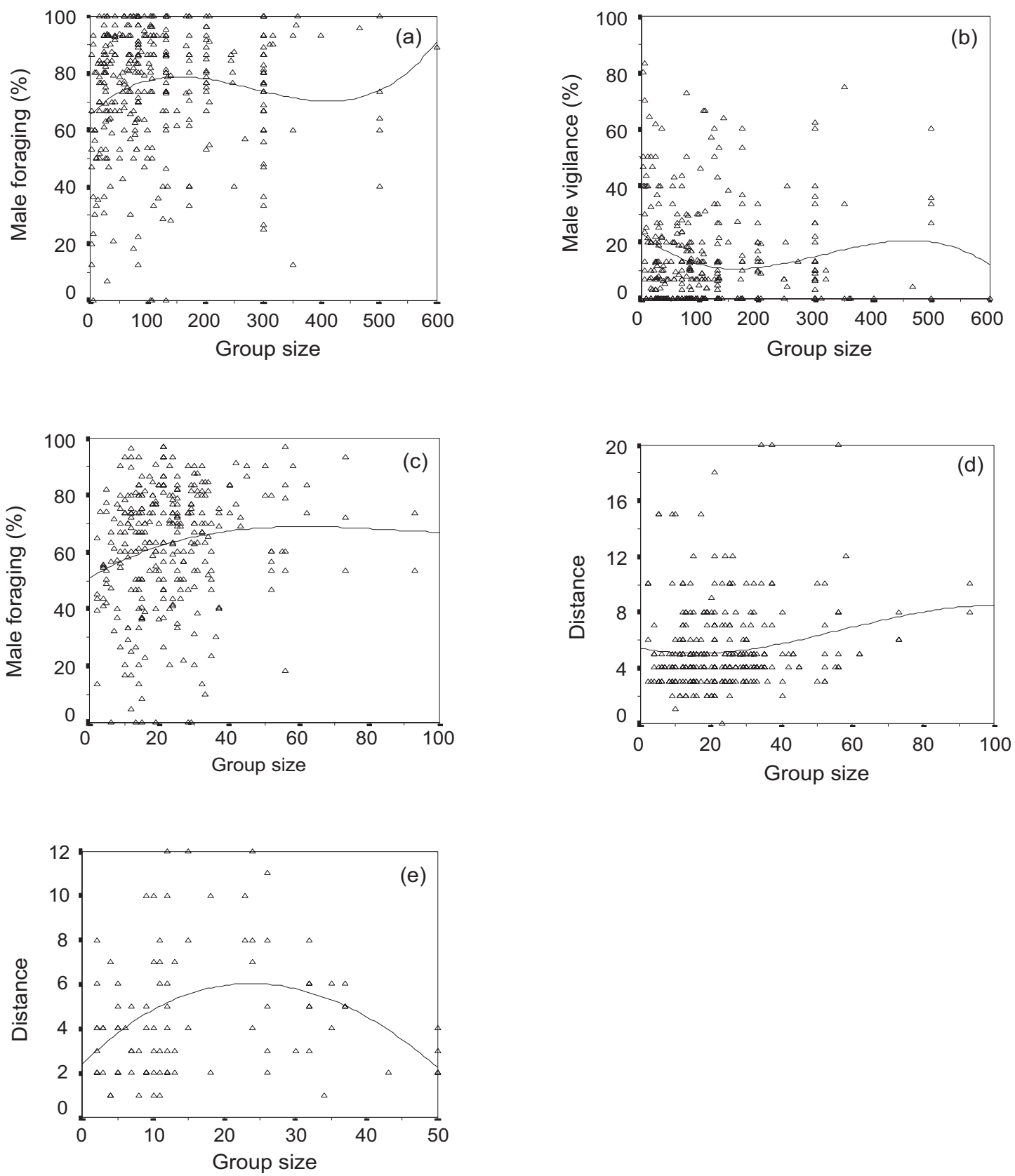

Figure 2. Scattergram with curve estimation (cubic models) of significant relationships between group size and male foraging and vigilance, and between group size and distance between the pair members. $a)-b)=$ Vesterålen, $c)-d)=$ Sassendalen, $e$ ) $=$ Pasvik. 
The curves appear to be more linear for smaller group sizes, so the tests were repeated for this data segment. Group sizes used were $<201$ geese in Vesterålen ( $\mathrm{n}=287-291),<41$ in Sassendalen $(n=281-285)$, and $<20$ in Pasvik $(n=59)$. A significant correlation was found for vigilancegroup size $(r=0.14, p=0.02)$ in Vesterålen, but with a small coefficient that explained only very little of the variation $\left(\mathrm{r}^{2}=0.02\right)$. In Sassendalen, foraging was correlated with group size as before ( $\mathrm{r}=0.14, \mathrm{p}=0.02$ ), but distance was not. In Pasvik, distance was positively correlated with group size for small groups $(\mathrm{r}=0.28, \mathrm{p}=0.03)$.

\section{DISCUSSION}

Geese are strictly monogamous and the male has an important role in keeping guard (Inglis 1976, Lazarus \& Inglis 1978). He may warn and protect the female against predators, protect her from being harassed by other geese, and selfishly «guard» her from mating with other males. Gauthier \& Tardif (1991) found a positive correlation between male vigilance and female feeding in Greater Snow Geese Chen caerulescens atlantia. The geese form lifetime pair bonds, but mate-guarding by the male may vary according to circumstances (compare Lazarus \& Inglis 1978, Bélanger \& Bédard 1992). Thus, geese are prime candidates for studies on the significance of vigilance, although several factors may confound such studies. Such confounding factors include the density and type of food, competition between individuals, the distance to either a safe place or the observer, the presence of predators, the visibility within habitats, the composition of the group, the ambient temperature and the time of day (Elgar 1989). None of these factors was thought to be of great significance in this study. Age and social rank may also have an effect (Quenette 1990).

Few significant relationships were found between male behaviour (vigilant, agonistic or foraging) and the three factors studied (group size, distance between the members of a pair, and position in the group). The statistically non-significant results supports the predator defence hypothesis more than the mate guarding hypothesis (compare Tables 1 and 5). In some cases, a non-linear relationship was found, which may indicate conflicting interests in the males. For example, in Vesterålen male vigilance decreased with group size for smaller groups, but increased for the largest groups. This may indicate increased social tension in the largest groups with high densities of geese, i.e. groups are only beneficial up to a certain size or density. Perhaps the geese cannot estimate the numbers in large groups, perhaps there is a threshold above which additional «eyes» are not needed (sensu Bekoff 1995), or perhaps the geese estimate density rather than actual numbers of geese. Density-dependent vigilance may agree more with the hypothesis of reduced individual predation risk in larger groups (Roberts 1996). In Sassendalen and Pasvik, the geese foraged more often in a line with all birds on the «forward edge», and smaller groups in Vesterålen also often tended to stretch out in a line. Possible effects of such differences in group geometry were not studied. Models integrating both conflicting interests may give a more correct picture of the relations (Figure 3, see Burger \& Gochfeld 1988). Many studies of primates have also failed to detect a group-size effect on vigilance (Treves 2000).

Vigilance was more prominent in Sassendalen than in Vesterålen, despite the groups being smaller. This may indicate an increased risk of predation (predation was only found in Sassendalen), increased competition for food, or both. Male agonistic behaviour was rare and at similar levels in both localities. The Bean Geese in Pasvik appeared to be intermediate in several respects, perhaps reflecting a less demanding migration route and breeding areas with greater primary productivity, and hence less competition. The Bean Geese could be expected to be more vigilant than the Pink-footed Geese because they were close to cover (forest) from which predators may more easily steal upon them. Although the Pink-footed Geese in Vesterålen were exposed to 


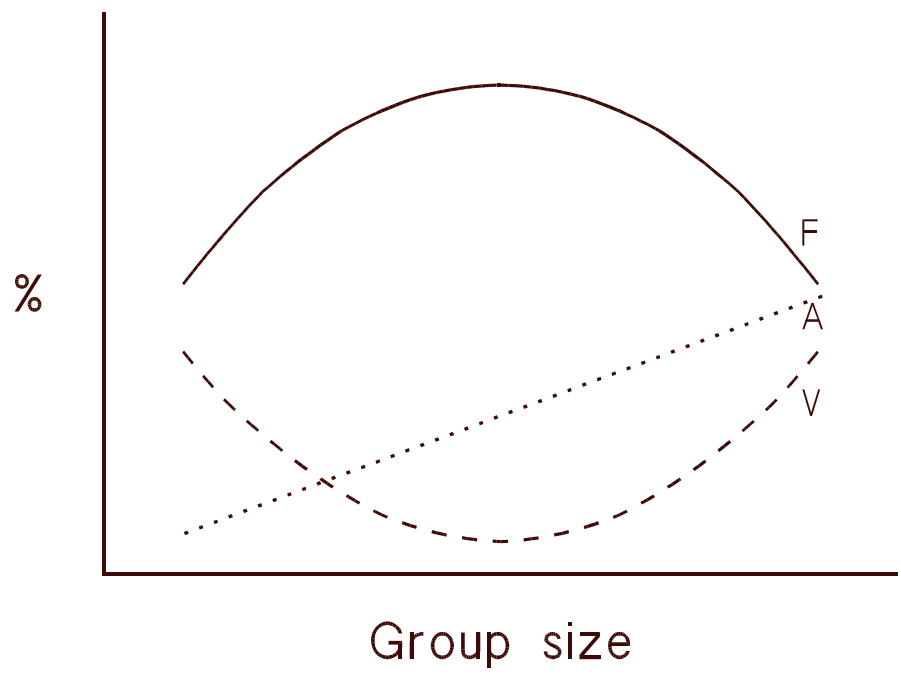

Figure 3. Predictions of the relationship between group size and foraging $(F)$, vigilance $(V)$, and agonistic behaviour (A) in male geese.

much human activity (including being chased off from some fields), this did not appear to increase vigilance by males. Both goose species are known to be very wary of humans, probably because they have been hunted for decades, but they are also able to adapt rapidly and can tolerate human activity when not hunted. Madsen (1998) reported how Pink-footed Geese exploited patches closer to buildings during quiet periods of the night, after more distant patches had been depleted (compare Sutherland \& Allport 1994).

Most or all adult geese were paired, and there was apparently no excess of adult males. The latter is often associated with the need for the male to guard his female against sneaky copulations by other males (sensu Artiss \& Martin 1995). Yearling males were probably no competition for adult males, but did sometimes cause agitation in a group. In Sassendalen where two geese, both probably females, were killed by Arctic Foxes, the two remaining unpaired males were a disturbing element for several days as they attempted to associate with other females. Lazarus (1978) and Inglis \& Lazarus (1981) offered an alternative explanation for reduced vigilance in larger groups: the edge effect. The fact that geese at the edge of a group are more vigilant and that the relative number of geese at the edge decreases as group size increases, may partly account for the relationship between group size and vigilance. Furthermore, foraging in edge positions may be energetically profitable and compensate for increased vigilance, because the food supply is less exhausted there (Black et al. 1992, sensu Madsen 1998).

Male vigilance in geese may help females to maximise food intake. Males «protect» a space around the female and also warn of danger. Competition for food may also exist in herbivores, and in geese this is probably manifested in the more dominant pairs (or families) occupying the best feeding sites (Stahl et al.2001). However, in large groups it could be more important to maximise feeding efficiency rather than to fight for exclusive rights to certain areas. Geese of high social status may also be able to select the best nesting sites. In this study, protection of paternity may not have been very 
important, since most matings are believed to take place before the spring migration starts. A lack of statistically significant relationships in this study does not mean that male vigilance is not important. More likely, the male makes the best of conflicting interests, with predator detection of greater importance.

\section{ACKNOWLEDGEMENTS}

Some of the work in Vesterålen was done as part of a Cand. Scient. thesis by Ivar Stevy. The work in Sassendalen was supported by a grant from the Norwegian Polar Institute (Stipend 21/94). Eivin Røskaft gave useful comments on the manuscript and Rob Barrett improved the English.

\section{SAMMENDRAG}

Vakthold hos hanner av kortnebbgås og sædgås: beskyttelse mot andre gjess eller mot rovdyr?

Flere studier har konkludert med at vakthold reduseres med $\varnothing$ kende gruppest $\varnothing$ rrelse. To hovedhypoteser er framsatt: 1) beskyttelse av partner mot andre gjess og 2) oppdage rovdyr. Følgende prediksjoner kan gjøres på grunnlag av tre faktorer; flokkstørrelse, avstand mellom hann og hunn og posisjon i flokken. For hypotese 1): (a) Vakthold og agonistisk atferd $\varnothing$ ker med $\varnothing$ kende flokkstørrelse, mens avstand innen paret avtar. (b) Vakthold $\varnothing$ ker med $\varnothing$ kende avstand innen paret, agonistisk atferd avhenger ikke av denne avstanden. (c) Vakthold og agonistisk atferd avtar når paret er i ytterkant av flokken, avstand kan $\emptyset$ ke. For hypotese 2): (d) Vakthold avtar med flokkstørrelse, avstand innen paret avhenger ikke av flokkstørrelse. (e) Vakthold avhenger ikke av avstand inne paret. (f) Vakthold øker når paret befinner seg i ytterkant av flokken, avstanden innen paret kan minke. (g) Agonistisk atferd avhenger ikke av noen av disse tre faktorene.
Gjess lever ofte i store flokker som er lette å observere. De er derfor gode objekter for å studere vakthold og agonistisk atferd hos hanner. Jeg studerte atferd hos kortnebbgås før hekking på Svalbard og på vårtrekket i Vesterålen. Sædgås ble studert på vårtrekket (vårbeiteplass) i Pasvikelva. Både beiting, vakthold og agonistisk atferd ble registrert, ved å følge et par om gangen. Dessuten ble flokkstørrelse, avstanden mellom hann og hunn i et par («gåselengder»), samt plassering i flokken (ytterkant eller inni) registrert. Overraskende nok ble svært få statistisk signifikante sammenhenger funnet. Den beste sammenhengen var at hanner var mer på vakt i ytterkant enn inni flokken. I noen tilfeller ble ikke-lineære sammenhenger funnet, f.eks. mellom flokkstørrelse og vakthold i Vesterålen. Totalt sett støtta dette hypotese 2) mer enn hypotese 1), men disse to hypotesene utelukker ikke hverandre. Hannen kan gjøre begge deler samtidig, der viktigheten av dem avhenger av tid og sted. Tatt $\mathrm{i}$ betraktning av at slike klare sammenhenger tidligere er påvist hos andre gjess, er mangelen på en effekt av flokkstørrelse og mangelen på støtte til prediksjonene likevel forbausende. Resultatene var imidlertid nokså like for de tre områdene og er derfor neppe tilfeldige. Flere tidligere studier er blitt kritisert av andre, og i enkelte tilfeller er det nok riktig å stille spørsmål ved hva som faktisk ble påvist.

\section{REFERENCES}

Artiss, T. \& Martin, K. 1995. Male vigilance in white-tailed ptarmigan, Lagopus leucurus: mate guarding or predator detection? - Anim. Behav. 49: 1249-1258.

Bekoff, M. 1995. Vigilance, flock size, and flock geometry: information gathering by western evening grosbeaks (Aves, Fringillidae). - Ethology 99: 150-161.

Bélanger, L. \& Bédard, J. 1992. Flock composition and foraging behavior of greater snow geese (Chen caerulescens atlantica). - Can.J.Zool. 70: 2410-2415.

Black, J.M., Carbone, C., Wells, R.L. \& Owen, M. 1992. Foraging dynamics in goose flocks: 
the cost of living on the edge. - Anim. Behav. 44: 41-50.

Black, J.M. \& Owen, M. 1988. Variations in pair bond and agonistic behaviors in barnacle geese on the wintering grounds. - Pp. 39-57 in Weller, D. (ed.): Waterfowl in winter. University of Minnesota Press, Minneapolis

Burger, J. \& Gochfeld, M. 1988. Effects of group size and sex on vigilance in ostriches (Struthio camelus): antipredator strategy or mate competition? - Ostrich 59: 14-20.

$\mathrm{B} \emptyset \mathrm{nes}, \mathrm{T}$. 1995. Kortnebbgåsregistreringen $i$ Vesterålen 1995. Unpublished report. Norsk Ornitologisk Forening, Vesterålen Lokallag.

Elgar, M.A. 1989. Predator vigilance and group size in mammals and birds: a critical review of the empirical evidence. - Biol. Rev. 64: 13-33.

Frafjord, K. 1990. A study of the pink-footed goose in Gipsdalen, Svalbard, during the pre-breeding and early breeding periods. - Norw. Polar Inst. Report no. 66: 1-18.

Gauthier, G. 1994. Foraging dynamics in goose flocks and the cost of living on the edge: a comment. - Anim. Behav. 48: 1476-1478.

Gauthier, G. \& Tardif, J. 1991. Female feeding and male vigilance during nesting in greater snow geese. - The Condor 93: 701-711.

Hamilton, W.D. 1971. Geometry for the selfish herd. - J. Theoret. Biol. 31: 295-311.

Inglis, I.R. 1976. Agonistic behaviour of breeding pink-footed geese with reference to Ryder's hypotheses. - Wildfowl 27: 95-99.

Inglis, I.R. \& Lazarus, J. 1981. Vigilance and flock size in brent geese: the edge effect. - Z für Tierpsychol. 57: 193-200.

Jeugd, H.P. van der \& Blaakmeer, K.B. 2001. Teenage love: the importance of trial liaisons, subadult plumage and early pairing in barnacle geese. - Anim. Behav. 62: 1075-1083.

Kotrschal, K., Hemetsberger, J. \& Dittami, J. 1993. Food exploitation by a winter flock of greylag geese: behavioral dynamics, competition and social status. - Behav. Ecol. Sociobiol. 33: 289-295.

Lazarus, J. 1978. Vigilance, flock size and domain of danger size in the white-fronted goose. Wildfowl 29: 135-145.

Lazarus, J. \& Inglis, I.R. 1978. The breeding behaviour of the pink-footed goose: parental care and vigilant behaviour during the fledging period. - Behaviour 65: 62-88.

Lima, S.L. \& Zollner, P.A. 1996. Anti-predatory vigilance and the limits to collective detection: visual and spatial separation between foragers. - Behav. Ecol. Sociobiol 38: 355-363.

Madsen, J. 1998. Changing trade-offs between predation risk and food intake: Gaining access to feeding patches during spring-fattening in pink-footed geese Anser brachyrhynchus. - Norsk Polarinst. Skrifter 200: 303-311.

Owen, M. 1981.Abdominal profile: A condition index for wild geese in the field. - J. Wildl.Manage . 45: 227-230.

Quenette, P.-Y. 1990. Functions of vigilance behaviour in mammals: a review. - Acta Oecol. 11: 801-818.

Roberts, G. 1996. Why individual vigilance declines as group size increases. - Anim. Behav. 51: 1077-1086.

Stahl, J., Tolsma, P.H., Loonen, M.J.J.E. \& Drent, R.H. 2001. Subordinates explore but dominants profit: resource competition in high Arctic barnacle goose flocks. - Anim. Behav. 61: 257-264.

Sutherland, W.J. \& Allport, G.J. 1994. A spatial depletion model of the interaction between bean geese and wigeon with the consequences for habitat management. - J. Anim. Ecol. 63: 51-59.

Treves, A. 2000. Theory and method in studies of vigilance and aggregation. - Anim. Behav. 60: 711-722. 